American Journal of Biochemistry and Biotechnology 6 (3): 164-171, 2010

ISSN 1553-3468

(C) 2010 Science Publications

\title{
Detection and Localization of Anti and Pro-apoptotic mRNA Genes in Human Colorectal Cancer Using in situ RT-PCR
}

\author{
${ }^{1}$ Mohd. Nazil Salleh, ${ }^{2}$ Boo Siaw Shi, ${ }^{1}$ Wan Khairuzzaman Wan Ramli, \\ ${ }^{1}$ Azlina Zahari, ${ }^{3}$ Norashikin Shamsudin and ${ }^{4}$ Thuaibah Hashim \\ ${ }^{1}$ Department of Medical Laboratory Technology, Faculty of Biomedical and Health Sciences, \\ University Industry Selangor, Section 7, 40000 Shah Alam Selangor, Selangor, Malaysia \\ ${ }^{2}$ Department of Biomedical Sciences, Faculty of Medicine and Health Sciences, \\ ${ }^{3}$ Department of Medicine, Faculty of Medicine and Health Sciences, \\ University Putra Malaysia, 43400 UPM Serdang, Malaysia \\ ${ }^{4}$ Department of Histopathology, No. 3410, Jalan Teknokrat 3, \\ Cyber 4, 63000 Cyberjaya, Cyberjaya University College of Medical Sciences, Malaysia
}

\begin{abstract}
Problem statement: Recent studies using conventional Polymerase Chain Reaction have shown that anti-apoptotic (Cyclooxygenase-2, COX-2 and Nuclear Factor- $\kappa \mathrm{B}, \mathrm{NF}-\kappa \mathrm{B}$ ) and proapoptotic mRNA (Bax and Bad) are involved in the tumorigenesis of colorectal cancer. The aim of this study was to localize the expression of anti and pro-apoptotic mRNA genes using Reverse Transcription in situ Polymerase Chain Reaction (RT in situ PCR) and immunodetection technique in the early stage of human colorectal adenocarcinoma. Approach: Reverse Transcription in situ Polymerase Chain Reaction (RT in situ PCR) and immunodetection technique was applied throughout of this studies. 20 paraffin-embedded tissue blocks of human colorectal adenocarcinoma samples was used compared to controls. Results: Morphologically, the glands and crypts were well-differentiated, enlarged and irregular with active secretion of mucin. COX-2, NF- $\mathrm{B}, \mathrm{Bax}$ and Bad mRNA were expressed in both normal and human colorectal cancer tissues. All mRNA genes were expressed in the cytoplasm and nuclei. However, COX-2 and NF- $\kappa$ B mRNA genes were highly expressed with higher intensity of brown staining compared to Bax and Bad at tubular epithelium cells. Conclusion: This study demonstrated that by using RT in situ PCR, COX-2 and NF- $\mathrm{B}$ mRNA genes were shown to be involved in the development of human colorectal cancer.
\end{abstract}

Key words: Cyclooxygenase-2 (COX-2), Nuclear Factor- $\kappa \mathrm{B}(\mathrm{NF}-\kappa \mathrm{B})$, heterodimeric partner for Bcl$\mathrm{XL}$ and Bcl-2 (Bad), bcl-2 associated X protein (Bax), in situ Reverse Transcription Polymerase Chain Reaction (in situ RT-PCR)

\section{INTRODUCTION}

Colorectal cancer is the second leading cause of death in western countries (Rainford, 2000; Ruegg et al., 2004; Midgley and Kerr, 1999). According to Malaysia Ministry of Health, Human Colorectal Cancer (HCC) ranked third among cancer cases reported, accounting for 7.8 and $5.6 \%$ in males and females respectively (Lim, 2006). Unfortunately, the peak incidence for colorectal cancer is 60-70 years of age and highest among Chinese (King and Robins, 2006).

Colorectal cancer, including the rectum, is the host to more primary neoplasms than any other organ in the body. About $90 \%$ of the colon cancer characterized as adenocarcinoma whereas the other $10 \%$ is mucinous adenocarcinoma (King and Robins, 2006). Approximately 98\% of all cancers in the large intestine are adenocarcinomas (Robbins, 2004). This disease is curable in early stages (Tsuji et al., 1997). Adenocarcinoma is malignant epithelial tumor arising from glandular structures, which are constituent parts of most organs of the body and tumors showing a glandular growth pattern (Wiesner et al., 2003).

In this study, an RT in situ PCR method was conducted to investigate the expression of antiapoptotic (COX-2 and NF-кB) and pro-apoptotic (Bax

Corresponding Author: Mohd. Nazil Salleh, Department of Medical Laboratory Technology,

Faculty of Biomedical and Health Sciences, University Industry Selangor, Section 7,

40000 Shah Alam Selangor, Selangor, Malaysia Tel: 603-5522 3421 Fax: 603-5522 3523 
and Bad) mRNA in human colorectal adenocarcinoma. These four genes are believed to be involved closely in the tumorigenesis in human colorectal adenocarcinoma. COX-2 mRNA expression detected at higher levels than in normal colorectal mucosa (Hasegawa et al., 2001). Nuclear Factor- $\kappa B$ (NF- $\kappa B$ ) is a transcription factor which plays an important role in inducible expression of diverse cellular genes, mostly involved in host defense such as genes for various cytokines, cellsurface receptors (Fujimoto et al., 1995) play and plays a role in the pathogenesis in intestinal mucosa. Native Bax become apoptotic even without external stimuli and without blocking the antiapoptotic activity (Ishibashi et al., 1998). Bad gene, the Bcl-XL/Bcl-2associated death promoter, has been shown to be mutated occasionally in colon cancers and that somatic mutation of Bad may contribute to the development of colon cancers (Lee et al., 2004).

The present study was using RT in situ PCR technique which allows detection of very low copy of mRNA in cellular level with rapid and sensitively method to investigate a specific mRNA gene was applied. In conclusion, our findings had shown that, the expression of COX-2, NF- $\kappa B$, bad and bax mRNA was detected in early stage development of colorectal adenocarcinoma/tumorogenesis.

\section{MATERIALS AND METHODS}

Preparation of tissue sections: Human colon and rectal cancer samples $(n=20)$ obtained underwent normal histological process. The tissues are sectioned at the thickness of $4 \mu \mathrm{m}$ and placed on microscopic glass sides for $\mathrm{H} \& \mathrm{E}$ staining for histopathological examination and topological orientation whilst tissue sections fished on silane-coated slides were preceded with RT in situ PCR. This project was approved by the ethical committee of Faculty of Medicine and Health Sciences, Malaysia.

Processing and pre-treatment of tissue sections: Tissue sections were incubated for $2 \mathrm{~h}$ at $70^{\circ} \mathrm{C}$ in incubator to ensure tissue adhere to the slides. Tissue sections were dipped into xylene and ethanol with decreasing concentration. The slides were then washed with DEPC-treated water until clean and dried for $10 \mathrm{~min}$ at rt. Sections were treated with $7.5 \mu \mathrm{g} \mathrm{mL}^{-1}$ Proteinase $\mathrm{K}$ for $45 \mathrm{~min}$ at $37^{\circ} \mathrm{C}$ on heat block. Tissue digestion conditions were standardized by optimizing in graded concentration of Proteinase $\mathrm{K}$ to an optimal time. These steps are necessary in order to preserve morphology and to facilitate the access of the RT-PCR mixture to the nucleic acid sequences. PBS was used to wash off Proteinase $\mathrm{K}$ and its digestion was inactivated at $95^{\circ} \mathrm{C}$ for $1 \mathrm{~min}$ on heat block. The slides were then rinsed firstly in PBS, followed by in DEPC-treated water and then air-dried. The genomic DNA in each section was digested with $50 \mu \mathrm{L}$ RNase-free DNase I $(20 \mathrm{U})$ overnight at $37^{\circ} \mathrm{C}$ in humid chamber to avoid non-specific amplification of the DNA by the Tfl DNA polymerase. Optimization was done by testing different concentration of DNase I and different time exposure. After DNase treatment, the slides were thoroughly washed with DEPC water for $1 \mathrm{~min}$, followed by $100 \%$ ETOH for 1 min and air-dried.

Labeling of probes: Six groups of 20-mer oligonucleotide probes (Table 1) complementary to p53, p21 and bax mRNA were synthesized. The sequences were labeled by tailing the $3^{\prime}$ end using digoxigenin-11-dUTP. The primers were designed online using Primer3 (www.primer3.com).

One-step RT in situ PCR assay: A modified one-step RT in situ PCR approach was performed using the techniques of Nuovo (1996). Tissue section was outlined with in situ Frame. Each slide was loaded with $50 \mu \mathrm{L}$ of a RT-PCR mixture which consists of $30.0 \mu \mathrm{L}$ Nuclease-free water, $10.0 \mu \mathrm{L} \mathrm{AMV/Tfl} 5 \mathrm{X}$ reaction buffer, $2.0 \mu \mathrm{L}$ of $25 \mathrm{~mm} \mathrm{MgSO}$, $2.0 \mu \mathrm{L}$ of $510 \mathrm{~mm}$ dNTP, $1.0 \mu \mathrm{L}$ for each forward and reverse primer (p53, p21 and Bax), 1.5 $\mu \mathrm{L} 2 \%$ BSA, 0.5 $\mu \mathrm{L}$ digoxigenin- 11-dUTP, $1.0 \mu \mathrm{L}$ AMV Reverse Transcriptase $\left(5 \mu \mu \mathrm{L}^{-1}\right)$ and $1.0 \mu \mathrm{L}$ of Tfl DNA polymerase $\left(5 \mu \mu \mathrm{L}^{-1}\right)$. An incubation chamber was made with an in situ cover slip and the sections stabilized by an in situ adapter in Eppendorf Mastercycler (Germany) with in situ block. Reverse transcription was performed on $45^{\circ} \mathrm{C}$ for $45 \mathrm{~min}$. Subsequently the incubation was followed by hot start for initial denaturation, which was carried out at $94^{\circ} \mathrm{C}$ for 2 minutes. Denaturation steps was performed at $94^{\circ} \mathrm{C}$ for $45 \mathrm{sec}$, annealing at $53^{\circ} \mathrm{C}$ for $40 \mathrm{sec}$, elongation at $68^{\circ} \mathrm{C}$ for $1 \mathrm{~min}$ and repeated for 34 cycles followed by final elongation at $68^{\circ} \mathrm{C}$ for $4 \mathrm{~min}$ and finally cooled at $4^{\circ} \mathrm{C}$ for $10 \mathrm{~min}$.

Table 1: Eight groups of 20-mer oligonucleotide probes complementary to Bax, Bad, COX-2 and NF- $\mathrm{BB}$ mRNA were synthesized. The primers were designed online by using Primer3 (www.primer3.com)

\begin{tabular}{|c|c|c|c|}
\hline Primers & & Sequences & Length (bps) \\
\hline \multirow[t]{2}{*}{$\overline{\text { Bax }}$} & Sense & $\begin{array}{l}\text { 5'-TTTGCTTCAGGGTTTCATCC-3' } \\
\end{array}$ & 246 \\
\hline & Antisense & 5'-CAGTTGAAGTTGCCGTCAGA-3' & \\
\hline \multirow[t]{2}{*}{$\mathrm{Bad}$} & Sense & 5'-CGGAGGATGAGTGACGAGTT-3' & 180 \\
\hline & Antisense & 5'-GATGTGGAGCGAAGGTCACT-3' & \\
\hline \multirow[t]{2}{*}{$\mathrm{COX}-2$} & Sense & 5'-TGAGCATCTACGGTTTGCTG-3' & 158 \\
\hline & Antisense & 5'-TGCTTGTCTGGAACAACTGC-3' & \\
\hline \multirow[t]{2}{*}{ NF-kB } & Sense & 5'-GCGAGAGGAGCACAGATACC-3' & 250 \\
\hline & Antisense & 5'-CTGATAGCCTGCTCCAGGTC-3' & \\
\hline
\end{tabular}

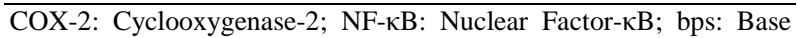
pairs 
Immunodetection of PCR products: After RT-PCR process, in situ Frame was gently removed and the slides were flooded with PBS for 5 min to saturate the non-specific sites and then washed in PBS twice time properly. Endogenous peroxidase in the specimen was blocked by incubating in 6\% hydrogen peroxide in absolute methanol for $30 \mathrm{~min}$ in dark humid chamber and followed by rinsing with PBS in Tween 20 for 2 min. The slides were then treated with BSA for $15 \mathrm{~min}$ in humid chamber. The slides were flooded with PBS in Tween 20 for 2 min and then washed slides with PBS in Tween 20 for $10 \mathrm{~min}$. To visualize the PCR signal, digoxigenin-labeled PCR products were detected by incubating with $50 \mu \mathrm{L}^{-1}$ anti-digoxigenin-gold $150 \mathrm{U} \mathrm{m}$ $\mathrm{L}^{-1}$ diluted in 1:30 with BSA in PBS (1 mg BSA $1 \mathrm{~mL}^{-1}$ PBS) $\mathrm{pH} 7.5$ for $30 \mathrm{~min}$ at $\mathrm{rt}$ in humid chamber. The slides will be washed in $0.05 \%$ Tween 20 in PBS and then in deionised water. The sections were developed for $12 \mathrm{~min}$ at $\mathrm{rt}$ with $100 \mu \mathrm{L}$ DAB chromogen in dark until brown color development was visible. The slides were flooded with $0.05 \%$ Tween 20 in PBS and were then rinsed $\mathrm{n}$ distilled water. The slides were then counterstained with Hematoxylin and continued with dehydration procedure by dipping into ethanol with increasing concentration and xylene. The slides were mounted with DPX and covered with coverslips. The slides were observed under light microscope and analysis of image will be carried out.

\section{RESULTS}

Histological analysis: Colon tissue sections are stained by using $\mathrm{H} \& \mathrm{E}$ staining to observe the morphological changes of these sections. In Plate 1A and 1B, these sections showed that well-differentiated, hyperplastic and irregular glands are crowded within mucosal layer. Some glands are enlarged (Plate 1A) and some crypts are distorted and some epithelial lining of the glands have lost its normal architecture (Plate 1B). The nuclei are stratified but still remain in the basal half of the cells (Plate 1C). In, addition most of the glands showed active mucin secretion activity (Plate $1 \mathrm{C}$ and $\mathrm{D}$ ). There is no invasion observed in these cases. Amorphous debris was observed in the lumen of the glands as shown in Plate 1A and C.

\section{Reverse Transcription in situ Polymerase Chain Reaction (RT in situ PCR):}

Optimization of positive and negative control: In our study, strong brown staining was observed in most cells with positive control and no brown staining was observed in the negative controls were prerequisite for success with RT in situ PCR. In positive control, the tissue was pretreated with Proteinase K without DNase I digestion. Plate $2 \mathrm{~A}$ showed a very strong intense brown staining demonstrates that proteinase $\mathrm{K}$ digestion was effective and subsequent PCR steps were successful. As for negative control, tissues were pretreated with Proteinase $\mathrm{K}$ and DNase I digestion but with omission of antidigoxigenin-gold (Plate 2B), DNA polymerase (Plate 2C), digoxigenin-11-dUTP (Plate 2D) and primer (Plate 2E). All the negative controls showed no brown staining which indicate that the products detected was indeed cDNA and not priming from contaminating genomic DNA.

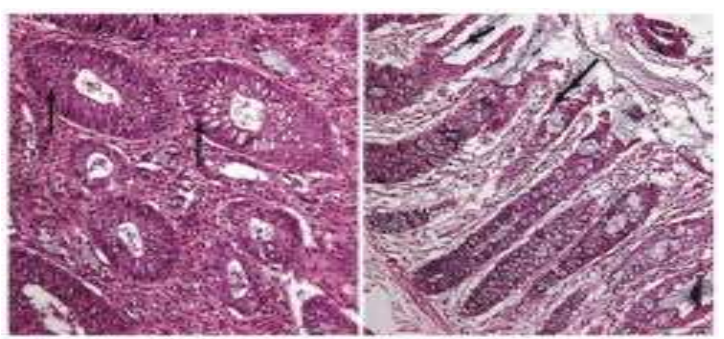

(A)

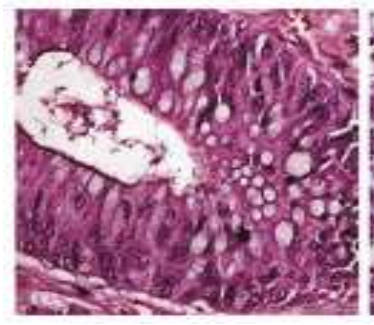

(C)
(B)

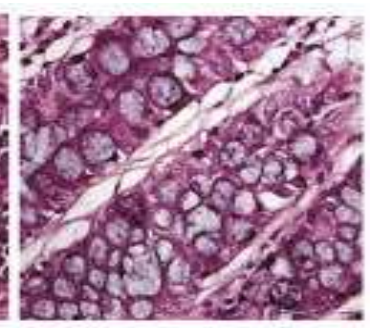

(D)
Plate 1: These are human colon adenocarcinoma ections stain with H\&E staining. (A) Well differentiated adenocarcinoma of colon. This section shows crowded neoplastic and enlarged glands. In between the glands, there is infiltration of inflammatory cells. There is amorphous debris (arrow) in the lumen of the neoplastic glands at magnification 100X. (B) Well differentiated glands show active mucin secretion as there is increase in number of goblet cells. The epithelial lining of the glands seem to be hyperplastic. Some glands have lost their normal architecture (arrow). The lamina propria is infiltrated with inflammatory cells at magnification 100X. (C) The enlarged nuclei are stratified but mostly remain in the basal half of the cells. Amorphous debris can be observed in the lumen of the glands (arrow) at magnification 400X. (D) The glands are full of goblet cells. In the lamina propria, the inflammatory cells (basophilic cells) show scanty cytoplasm (arrow) at magnification 400X 


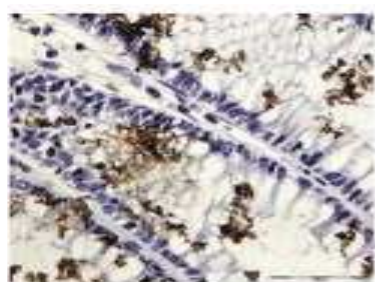

(A)

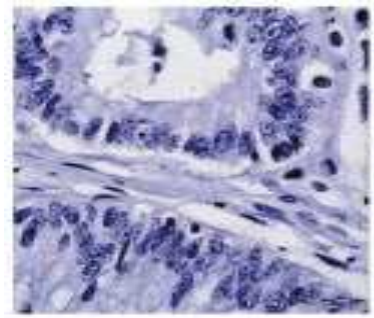

(C)

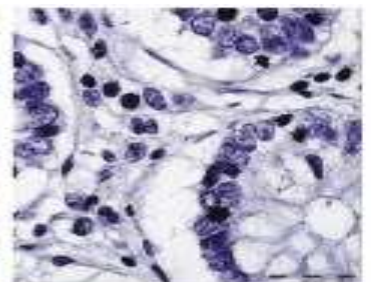

(B)

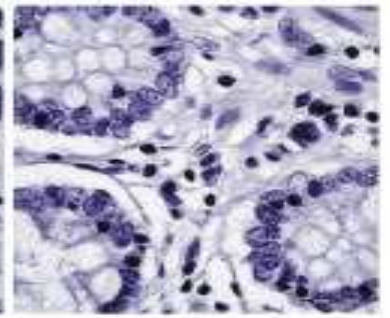

(D)

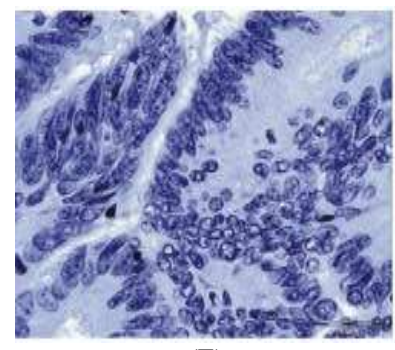

(E)

Plate 2: These are controls done by using $\mathrm{RT}$ in situ PCR technique at magnification 400X. (A) This is the positive control with omission of DNase treatment done on human rectal adenocarcinoma section. The intensity of nuclear very strongly intense. (B) The negative control with omission of anti-digoxigeningold. No brown staining is observed. (C) The negative control with omission of DNA polymerase. No brown staining is observed. (D) The negative control with omission of digoxigenin-11-dUTP. No brown staining is observed. (E) The negative control with omission of primer. No brown staining is observed

Expression of Cox-2, NF- $\kappa$ B, Bax and Bad mRNA: In normal colon tissue, the glands were lined with unbranched simple tubular epithelial cells at magnification of 400X. All four genes, Bax, Bad, COX2 and NF- $\mathrm{KB}$ were found to be expressed in the normal colon tissues. Bax gene was found in cytoplasm and nuclei of gland cells (Plate 3A). In Plate 3B, brown staining was observed the mucin producing glands but not in the gland without mucin secretion activity. Bad gene was found in both cytoplasm and nuclei.

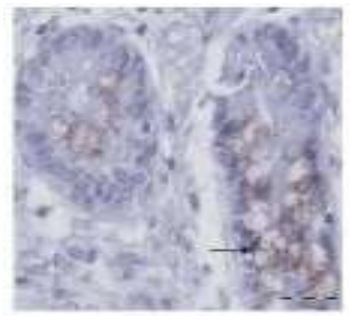

(A)

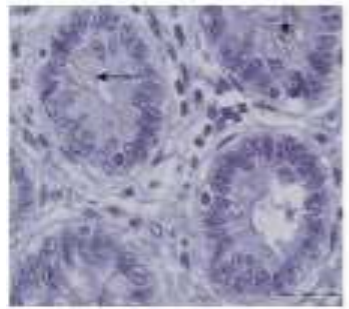

(C)

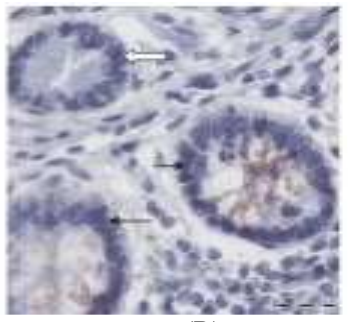

(B)

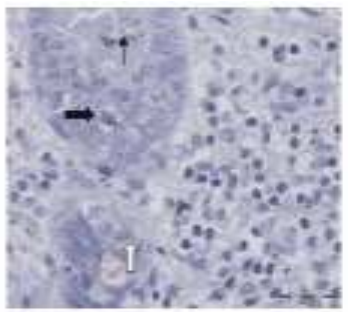

(D)
Plate 3: RT in situ PCR detection of anti- and proapoptotic mRNA in normal human colon sections at magnification 400X. (A) Detection of Bax mRNA. The glands are lined by unbranched simple tubular epithelial cells. Brown staining can be observed in the cytoplasms and nuclei (arrow) of the glands. (B) Detection of Bad mRNA. Brown staining is observed in the mucin producing glands (black arrow) but not in the gland which do not have mucin secretion activity (white arrow). Brown staining can be observed in the cytoplasm and nuclei (arrow). (C) Detection of COX-2 mRNA. Brown staining can be seen in some of the columnar epithelial cells of the glands (arrow). (D) Detection of NF- $\mathrm{KB}$ mRNA. Brown staining can be detected in the cytoplasm (arrow) as well as in the nucleus (close arrow) with prominent nucleolus (white arrow)

COX-2 gene was found to be expressed in the columnar epithelial cells of the glands (Plate 3C). While NF- $\mathrm{kB}$ gene was observed in cytoplasm and nucleus in normal colon tissue (Plate 3D).

In colon adenocarcinoma section, some glands showed active mucin secretion activity (Plate 4A-D). Bax gene was found in cytoplasm and nuclei of the glands as shown in Plate 4A. Bad gene was also found in both 7 cytoplasm and nuclei as shown in Plate 4B. In Plate $4 \mathrm{C}, \mathrm{COX}-2$ gene was found to be expressed in both cytoplasm and nuclei in human colon adenocarcinoma tissue. In Plate $4 \mathrm{D}, \mathrm{NF}-\kappa \mathrm{B}$ gene was observed to be expressed in both nuclei and cytoplasm of the glands in human colon adenocarcinoma tissue. 


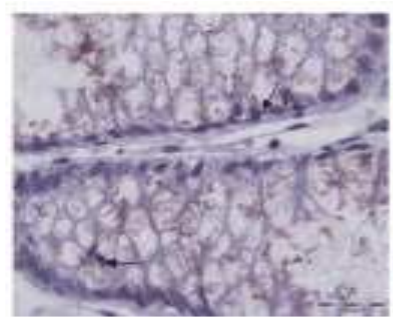

(A)

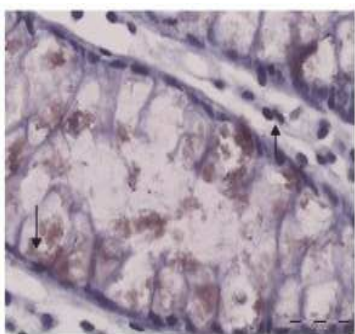

(C)

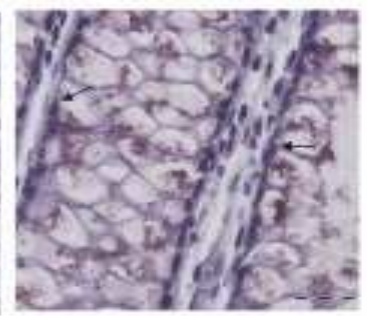

(B)

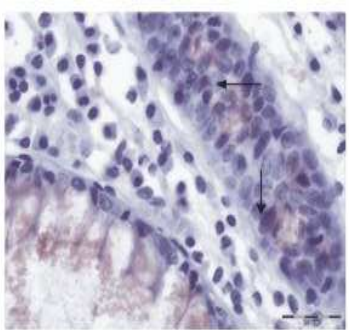

(D)
Plate 4: RT in situ PCR detection of anti- and proapoptotic mRNA in human colon adenocarcinoma sections at magnification 400X. (A) Detection of Bax mRNA. The glands show active mucin secretion activity. Brown staining can be detected in the cytoplasm and nuclei of the glands (arrow). (B) Detection of Bad mRNA. The glands show active mucin secretion activity. Brown staining can be detected in the cytoplasm and nuclei of the glands (arrow). (C) Detection of COX-2 mRNA. The glands show active mucin secretion activity. Brown staining can be detected in the cytoplasm and nuclei of the glands (arrow). (D) Detection of NF- $\mathrm{BB}$ mRNA. The glands show active mucin secretion activity. Brown staining can be detected in the cytoplasm and nuclei of the glands (arrow)

In rectal adenocarcinoma tissue at magnification of 400X, the nuclei of the cells appear to be enlarged with prominent nucleoli, hyperchromatic (Plate 5A-C), some are in pencil shape (Plate $5 \mathrm{~A}$ ) and some are rounded (Plate 5B). In Plate 5A, the Bax mRNA was found to be expressed in cytoplasm as well as in the nucleus. Brown staining can be observed in cytoplasm and nucleus for detection of Bad mRNA as shown in Plate 5B. Meanwhile, COX-2 mRNA can be observed in the cytoplasm and nucleus (Plate 5C). NF- $\kappa B$ was found to be expressed in cytoplasm and nucleus (Plate 5D).

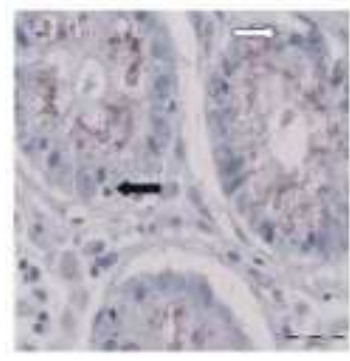

(A)

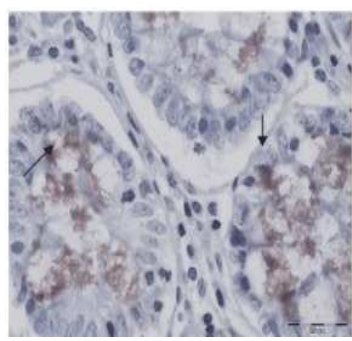

(C)

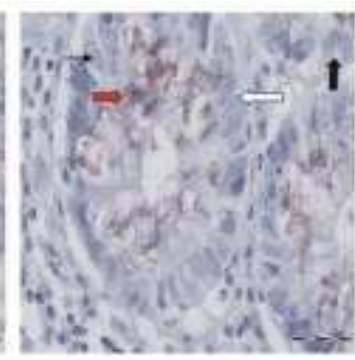

(B)

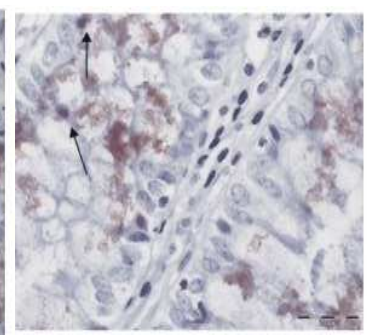

(D)
Plate 5: RT in situ PCR detection of anti- and proapoptotic mRNA in human rectal adenocarcinoma sections at magnification 400X. (A) Detection of Bax mRNA. The nuclei appear to be enlarged with prominent nucleoli (close arrow), hyperchromatic and some are in. (B) Detection of Bad mRNA. Nuclei of the glands are irregular in shape, some are rounded (arrow) and some are elongated (open arrow). Nuclei are hyperchromatic with prominent nuclei (close arrow). Brown staining can be observed in the cytoplasms as well as the nucleus (red arrow) of the glands. (C) Detection of COX-2 mRNA. The nuclei are irregular, hyperchromatic and vascular with prominent nucleoli. Brown staining can be observed in the cytoplasms as well as in the nucleus (close arrow). (D) Detection of NF- $\mathrm{kB}$ mRNA. Brown staining can be visible in the cytoplasm as well as in the nucleus (arrow). Some nuclei are enlarged

In normal colon tissue, brown staining was observed in glandular cells for the detection of Bax and Bad (Plate 3A and 3B) with higher intensity compared to $\mathrm{COX}-2$ and NF- $\mathrm{BB}$ (Plate $3 \mathrm{C}$ and $3 \mathrm{D}$ ) mRNA respectively. In all cases, brown staining was observed for the detection of Bax, Bad, COX-2 and NF- $\mathrm{BB}$ mRNA genes in nuclei and cytoplasm of epithelial cells of the glands (Plate 4A, 4B, 4C and 4D). However, intensity of brown staining for $\mathrm{COX}-2$ and NF- $\mathrm{KB}$ (Plate 4C and 4D) mRNA was observed to be higher 
compared to Bax and Bad (Plate 4A and 4B) in colon adenocarcinoma tissue.

\section{DISCUSSION}

Colorectal cancer has long been associated with disturbances in apoptosis regulation. The rate of tumor growth depends on the balance between proliferation and apoptosis at all stages of carcinogenesis (Samojednya et al., 2004). Epidemiological studies have indicated a negative relationship between colon cancer risk and the use of Nonsteroidal AntiInflammatory agents (NSAIDs) (Williams et al., 1997). Contrastingly, Hanif et al. (1996) and Giovannucci et al. (1994) showed that NSAIDs inhibit the proliferation rate, alter the cell cycle distribution and induce apoptosis in colon cancer cell lines.

In our present study, anti-apoptotic (COX-2 and NF- $\kappa B$ ) and pro-apoptotic (Bax and Bad) mRNA are expressed in the human colon and rectal adenocarcinoma tissue by using RT in situ PCR. COX2 and NF- $\mathrm{kB}$ are highly expressed compared to Bax and Bad mRNA in the human colon and rectal adenocarcinoma samples. Colon tissue sections are stained by using H\&E staining to observe the morphological changes which show these welldifferentiated glands with mucin secretion activity are enlarged and some are irregular in shape. Some crypts are distorted. The nuclei are irregular, enlarged, hyperchromatic and with prominent nucleoli. The nuclei are striated but still remain in the basal half of the cells. No invasion was observed.

In the present study, brown staining observed in all the colorectal adenocarcinoma cases which showed that Bax, Bad, COX-2 and NF-kB mRNA are expressed in both normal and cancerous cells. These genes were found to be expressed in nuclei and cytoplasm of epithelial cells of the glands.

COX-2 and NF- $\mathrm{KB}$ mRNA can be observed to be expressed in all the glands in the cancerous tissues. In normal tissue, Bax and Bad mRNA are expressed in the glands and crypts near the superficial epithelial lining with the intensity of brown staining stronger compared to COX-2 and NF- $\mathrm{KB}$ mRNA. In all colorectal tissues, COX-2 and NF- $\mathrm{KB}$ mRNA showed stronger intensity of brown staining than Bax and Bad mRNA. Thereby, our finding suggesting that, anti-apoptotic mRNA might be highly or overexpressed whereas pro-apoptotic mRNA might be under-expressed or suppressed in human colorectal adenocarcinoma.

In cancer cells, induction of Bax initiates cell death. Bax overexpression increases apoptosis induced by chemotherapeutic agents (Kobayashi et al., 2000).
Bax may induce apoptosis via pore-formation, BH3 domain. Bad can interact with anti-apoptotic genes of $\mathrm{Bcl}$ family and antagonizes their anti-apoptotic functions. Bad gene may have undergone some somatic mutation; Bad mutant had the ability to retain its proapoptotic function (Adachi and Imai, 2002).

COX-2, the inducible isoform, is regularly expressed at low levels in colonic mucosa. COX-2 may contributes to carcinogenesis and the malignant phenotype of tumor cells by inhibiting apotosis, increasing angiogenesis, increasing invasiveness, modulating inflammation or immuno-suppression and conversion of procarcinogens to carcinogens (Dempke et al., 2001). COX-2 expression is highly expressed (Kargman et al., 1995; Eberhart et al., 1994; Williams et al., 1996) detected and in $80-90 \%$ of colorectal adenocarcinomas (Maihofner et al., 2003). NF- $\kappa \mathrm{B}$ plays a crucial role in induction of COX-2 in various cell types (Mayo and Baldwin, 2000). In addition, NF- $\mathrm{KB}$ has been showed to play an important role in development of cancer and metastasis (Yang et al., 1999). It can antagonize p53 protein (Kher and Bacallao, 2001).

These anti- and pro-apoptotic mRNA may be expressed in low copy, which is not detectable. By using RT in situ PCR, it enhances sensitivity and thus enables localization of low abundance of mRNA in a cell. This method is also highly specific and enables the identification sites of RNA transcript production in tissues. By using formalin fixed, paraffin embedded, nucleus of a cell provides a relatively dense matrix of DNA, RNA and proteins, as they are extensively crosslinked to form a complex, 3-dimensional labyrinth. This method provides a higher surface to volume ratio (Nuovo, 1996). Protease digestion duration and DNase digestion is crucial to allow entrance of reagents and eliminate non-specific priming respectively.

In immunodetections, the non-radioactive digoxigenin-11-dUTP is end-labeled at the 3' end of the amplified mRNA. Digoxigenin is not found in mammalian cells. Anti-digoxigenin gold will bind go digoxigenin and can be detected by DAB chromogen, which is observed as brown staining.

\section{CONCLUSION}

Our findings conclude that COX-2, NF- $\mathrm{BB}$, Bax and $\mathrm{Bad}$ genes are expressed in human colorectal cancer and normal human colon in cytoplasm and/or nuclei of the cells. In comparing human normal and colorectal cancer, both anti-apoptotic genes are expressed at higher level compared to pro-apoptotic genes in colon adenocarcinoma tissue. Therefore, COX2 and NF-KB may contribute to the early stage of 
development of colorectal adenocarcinoma or tumorogenesis. Bax and Bad genes are also expressed to induce apoptosis to the proliferating glandular cells.

\section{ACKNOWLEDGEMENT}

We are grateful to Nor Hasni Shamsudin (Pathologist, Ministry of Health Malaysia) for providing human colorectal adenocarcinoma samples. There is no conflict of interest that would prejudice the impartiality of this study.

\section{REFERENCES}

Adachi, M. and K. Imai, 2002. The proapoptotic BH3only protein $\mathrm{BAD}$ transduces cell death signals independently of its interaction with Bcl-2. Cell Death Differ., 9: 1240-1247. DOI: 10.1038/sj.cdd.4401097

Dempke, W., C. Rie, A. Grothey and H.J. Schmoll, 2001. Cyclooxygenase-2: A novel target for cancer chemotherapy? J. Cancer Res. Clin. Oncol., 127: 411-417. DOI: 10.1007/S004320000225

Eberhart, C.E., R.J. Coffey, A. Radhika, F.M. Giardiello and S. Ferrenbach et al., 1994. Upregulation of cyclooxygenase-2 gene expression in human colorectal adenomas and adenocarcinomas. Gastroenterology, 107: 1183-1188. PMID: 7926468

Fujimoto, K., H. Yasuda, Y. Sato and K. Yamamoto, 1995. A role for phosphorylation in the proteolytic processing of the human NF-KB 1 precursor. Gene, 165: 183-189. DOI: 10.1016/0378-1119(95)00507-3

Giovannucci, E., E.B. Rimm, M.J. Stampfer, G.A. Colditz and A. Ascherio et al., 1994. Aspirin use and the risk for colorectal cancer in male health professionals. Ann. Int. Med., 121: 241-246. http://www.annals.org/content/121/4/241.abstract

Hanif, R., A. Pittus, Y. Fag, M.I. Koutsos and L. Qiao et al., 1996. Effects of nonsteroidal atiinflammatory drugs on proliferation and on induction of apoptosis in colon cancer cells by a prostaglandin-independent pathway. Biochem. Pharmacol., 52: 237-245. DOI: 10.1016/00062952(96)00181-5

Hasegawa, K., W. Ichikawa, T. Fujita, R. Ohno and T. Okusa et al., 2001. Expression of Cyclooxygenase-2 (COX-2) mRNA in human colorectal adenomas. Eur. J. Cancer, 37: 1467-1474. http://www.ejcancer.info/article/S09598049(01)00137-X/abstract
Ishibashi, Y., K. Nishimaki, S. Asoh, R. Nanbo-Wakao and T. Yamada et al., 1998. Pore formation domain of human pro-apoptotic Bax induces mammalian apoptosis as well as bacterial death without antagonizing anti-apoptotic factors. Biochem. Biophys. Res. Commun., 243: 609-616. DOI: 10.1006/bbrc.1998.8145

Lee, J.W., Y.H. Soung, S.Y. Kim, S.W. Nam and C.J. Kim et al., 2004. Inactivating mutations of proapoptotic Bad gene in human colon cancers. Carcinogenesis, 25: 1371-1376. DOI: 10.1093/carcin/bgh145

Kargman, S.L., G.P. O’Neill, P.J. Vickers, J.F. Evans and J.A. Mancini et al., 1995. Expression of prostaglandin $\mathrm{G} / \mathrm{H}$ synthase-1 and -2 protein in human colon cancer. Cancer Res., 55: 2556-2559. PMID: 7780968

Kher, R. and R. Bacallao, 2001. Direct in situ reverse transcriptase-polymerase chain reaction. Am. J. Physiol. Cell Physiol., 281: C726-C732. http://ajpcell.physiology.org/cgi/content/full/281/2/ C726

King, R.J.B. and M.W. Robins, 2006. Cancer Biology. 3rd Edn., Pearson/Prentice Hall, England, ISBN: 0131294547, pp: 292.

Kobayashi, T., H. Sawa, J. Morikawa, W. Zhang and H. Shiku, 2000. Bax induction activate apoptotic cascade via mitochondria cytochrome c release and Bax of the expression enhances apoptosis induced by chemotherapeutic agents in DLD-1 colon cancer cells. Jap. J. Cancer Res., 91: 1264-1268. DOI: 10.1111/j.1349-7006.2000.tb00913.x

Lim, G.C.C., 2006. Clinical oncology in Malaysia: 1914 to present. Biomed. Imag. Interv. J., 2: e18-e18. DOI: 10.2349/biij.2.1.e18

Maihofner,C., M.P. Charalambous, U. Bhambra, T. Lightfoot and G. Geisslinger et al., 2003. Expression of cyclooxygenase-2 parallels expression of interleukin-1 beta, interleukin-6 and NF-kappaB in human colorectal cancer. Carcinogenesis, 24: 665-671. DOI: $10.1093 /$ carcin/bgg006

Mayo, M.W. and A.S. Baldwin, 2000. The transcription factor $\mathrm{NF}-\kappa \mathrm{B}$ : Control of oncogenesis and cancer therapy resistance. Biochim. Biophys. Acta, 1470: M55-M62. DOI: 10.1016/S0304419X(00)00002-0

Midgley, R. and D. Kerr, 1999. Colorectal cancer. Lancet, 353: 391-399. PMID: 9950460

Nuovo, G.J., 1996. The foundation of successful RT in situ PCR. Front. Biosci., 1: c4-c15. http://www.bioscience.org/1996/v1/c/nuovo1/htmls /nuovo.pdf 
Rainford, L., 2000. Health in England 1998: Investigating the Links Between Social Inequalities and Health-A Survey of Adults Aged 16 and Over in England: Investigating the Links Between Social Inequalities and Health a Survey of Adults Aged 16 and Over in England Carried Out by the Social Survey Division of ONS on Behalf of the Health Education Authority. 3rd Edn., Stationery Office, London, ISBN: 0116213574, pp: 303.

Robbins, S.L., 2004. The Oral Cavity and Gastrointestinal Tract. In: Robbins and Cotran Pathologic Basis of Disease, Kumar, V., N. Fausto and A. Abbas (Eds.). Saunders, Philadelphia, ISBN: 10: 0721601871, pp: 582-584.

Ruegg, C., O. Dormond and A. Mariotti, 2004. Endothelial cell integrins and COX-2: Mediators and therapeutic of tumor angiogenesis. Biochimica Biophysica Acta (BBA)-Rev. Cancer, 1654: 51-67. DOI: 10.1016/j.bbcan.2003.09.003

Samojednya, M.P., D. Kokochinskab, A. Samojednya, U. Mazureka and R. Partykab et al., 2004. Expression of cell survival/death genes: Bcl-2 and Bax at the rate of colon cancer prognosis. Biochimica Biophysica Acta, 1741: 25-29. DOI: 10.1016/j.bbadis2004.11.021

Tsuji, M., S. Kawano and R.N. DuBois, 1997. Cyclooxygenase-2 expression in human colon cancer cells increases metastatic potential. Proc. Natl. Acad. Sci. USA., 94: 3336-3340. http://www.jstor.org/stable/41824
Wiesner, G.L., D. Daley, S. Lewis, C. Ticknor and P. Platzer et al., 2003. A subset of familial colorectal neoplasia kindreds linked to chromosome 9q22.2-31.2. PNAS, 100: 12961-12965. DOI: 10.1073/pnas. 2132286100

Williams, C.S., C. Luongo, A. Radhika, T. Zhang and L.W. Lamps et al., 1996. Elevated cyclooxygenase- 2 levels in min mouse adenomas. Gastroenterology, 111: 1134-1140. http://www.gastrojournal.org/article/S00165085(96)70083-5/abstract

Williams, C.S., W. Smalley and R.N. Dubois, 1997. Aspirin use and potential mechanisms for colorectal cancer prevention. J. Clin. Invest., 100: 1325-1329. DOI: 10.1172/JCI 119651

Yang, J.P., M. Hori, N. Takahashi, T. Kawabe, H. Kato et al., 1999. NF-кB subunit p65 binds to 53BP2 and inhibits cell death induced by 53BP2. Oncogene, $\quad$ 18: 5177-5186. http://www.nature.com/onc/journal/v18/n37/full/12 02904a.html 